\title{
The effect of different proportions of Medicago media Pers. in mixtures with Festulolium braunii (K. Richt.) A. Camus on the yield and feed value of green fodder
}

\author{
Marzenna Olszewska, Stefan Grzegorczyk and Anna Bałuch-Małecka \\ Department of Grassland and Green Space Management \\ University of Warmia and Mazury in Olsztyn, 10-719 Olsztyn, Poland \\ e-mail: marzenna.olszewska@uwm.edu.pl
}

\begin{abstract}
A field experiment was performed in 2011-2013. The aim of the study was to determine the effect of different proportions of Medicago media in mixtures with Festulolium braunii on the yield and feed value of green fodder, including the content of crude protein (CP) and water-soluble carbohydrates (WSC), and the carbohydrate-to-protein ratio. It was found that alfalfa had a high competitive advantage over Festulolium. In the second and third year of full utilization, alfalfa was the predominant species in the tested mixtures regardless of the proportion of sown seeds. The mixtures with alfalfa were characterized by high and stable dry matter yields and high protein content, whereas Festulolium significantly increased the content of WSC and improved the WSC:CP ratio. The evaluated mixtures had a higher feed value than pure-sown components. The results of the study indicate that Festulolium mixtures with a lower proportion ( $30 \%$ and $50 \%$ ) of alfalfa are characterized by a higher feed value.
\end{abstract}

Key words: chemical composition, forage biomass, grass, alfalfa

\section{Introduction}

Protein content and energy value are critical factors in qualitative evaluations of roughage for cattle. These parameters vary considerably and are influenced by numerous factors, including the species composition of the sward, the growth stage of plants, weather conditions, season and time of day (Andrzejewska et al. 2013, Mäkiniemi et al. 2016, Purwin et al. 2016, Staniak 2016, Staniak and Harasim 2018). Roughage deficient in protein and energy has to be supplemented with concentrate and specialty feed additives, which significantly increases costs and decreases production profitability (Huhtanen and Broderick 2016). The content of protein and carbohydrates, the main sources of energy, in fodder crops per hectare is a very important consideration in cattle farming, and it has been widely discussed in the literature (Peyraud et al. 2014, Peyraud and Peeters 2016, Johansen et al. 2016, Jankowski et al. 2018).

Due to its high protein content, alfalfa is one of the major feed ingredients around the world (Seppänen at al. 2018). In many countries, alfalfa is the basic component of feed rations for beef and dairy cattle. The main limitation of alfalfa as a feed ingredient is that its protein is less available for cattle than the protein from other types of roughage. The above can be attributed to the fact that alfalfa protein is readily soluble in water and undergoes rapid degradation in the rumen. Rapid decomposition of protein decreases the efficiency of its bacterial synthesis, which makes it difficult to meet the nutrient requirements of cattle with regard to protein digested in the small intestine. Microbial protein synthesis is also negatively affected by low concentrations of carbohydrates (Broderick 1995, Jafari 2012, Andrzejewska et al. 2013). Therefore, alfalfa should be grown with grasses to minimize protein loss. The presence of grasses in mixtures increases the carbohydrate content of biomass and contributes to the production of feed with an optimal energy and protein balance (Sosnowski 2011, Simili da Silva et al. 2013, Luscher et al. 2014, Vasileva and Naydenova 2017). According to the literature, feeds with a high content of water-soluble carbohydrates (WSC) improve protein utilization, which increases milk yields and body weight gains, and decreases nitrogen loss (Miller et al. 2001, Evans et al. 2011).

Research has demonstrated that Festulolium braunii is a highly suitable component in mixtures with alfalfa due to its high carbohydrate content (Sosnowski and Jankowski 2010, Sosnowski 2011, Olszewska and Kobyliński 2016, Staniak 2016, Staniak and Harasim 2018). The optimal proportion of component crops in mixtures is an important consideration. The aim of this study was to determine the effect of different proportions of alfalfa in mixtures with Festulolium on the yield and feed value of green fodder, including the content of crude protein (CP) and WSC, and the carbohydrate-to-protein ratio (WSC:CP). 


\section{Materials and methods \\ Field experiment}

The study was conducted in 2011-2013 in Poland. A small-area field experiment was performed at the Agricultural Experimental Station in Bałdy $\left(53^{\circ} 72^{\prime} \mathrm{N} ; 2^{\circ} 42^{\prime} \mathrm{E}\right)$ owned by the University of Warmia and Mazury in Olsztyn. The experiment was established on mineral soil of quality class IVa and very good rye complex according to the Polish soil classification system (Systematyka gleb Polski 1989). The arable layer was characterized by very low phosphorus content ( $4.6 \mathrm{mg} \mathrm{P}_{2} \mathrm{O}_{5}$ in $100 \mathrm{~g}$ of soil) and moderate concentrations of potassium (14.9 mg K $\mathrm{O}$ in 100 $\mathrm{g}$ of soil) and magnesium (5.0 mg in $100 \mathrm{~g}$ of soil). Soil $\mathrm{pH}$ was neutral $\left(\mathrm{pH}_{\mathrm{KCl}}\right.$ 7.2). The experiment was established in the spring of 2010, and it had a randomized block design with four replications. The analyzed species were Festulolium brauni $(\mathrm{Fb}) \mathrm{cv}$. Sulino and Medicago media $(\mathrm{Mm}) \mathrm{cv}$. Radius. The experimental factor was the proportion of alfalfa seeds in the mixture: $30 \%, 50 \%$ and $70 \%$. Pure-sown Festulolium and pure-sown alfalfa were the control treatments. Plot area was $10 \mathrm{~m}^{2}$. Before sowing, nitrogen, phosphorus and potassium fertilizers were applied to all plots at the following rates: $30 \mathrm{~kg} \mathrm{~N}, 80 \mathrm{~kg} \mathrm{P}_{2} \mathrm{O}_{5}$ and $60 \mathrm{~kg} \mathrm{~K}_{2} \mathrm{O} \mathrm{ha}^{-1}$. In pure-sown treatments, the seeding rate was $40 \mathrm{~kg} \mathrm{ha}^{-1}$ for Festulolium and $15 \mathrm{~kg} \mathrm{ha}^{-1}$ for alfalfa. In the experimental treatments, the seeding rates corresponded to the percentages of the analyzed species in the mixture. Seeds were broadcast, and cover crops were not used. In the years of full utilization, pure-sown Festulolium was fertilized with nitrogen at $180 \mathrm{~N} \mathrm{ha}^{-1}$, mixtures were fertilized with nitrogen at $90 \mathrm{~kg} \mathrm{~N} \mathrm{ha}^{-1}$, whereas pure-sown was not fertilized with nitrogen. Nitrogen fertilizer was split into three equal doses and applied in early spring, after the first and second harvest. All plots were

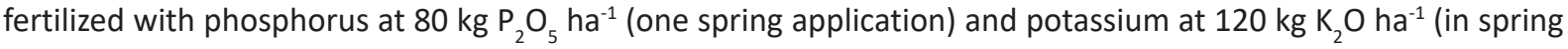
and after the first harvest).

\section{Botanical and chemical analyses}

The sward was mowed three times in every growing season. The first regrowth of mixtures was mowed at the beginning of Festulolium heading and the next one at the stage of lucerne budding. One-kilogram samples of green matter were collected after each harvest to determine the dry matter yield and the chemical composition of swards. The actual proportion of alfalfa in the mixtures was determined in botanical analyses on a weight basis. The content of WSC in plant material was determined with the anthrone reagent, and CP content was determined by the Kjeldahl method. The WSC:CP ratio were calculated.

\section{Statistical analysis}

The results were processed statistically by analysis of variance (ANOVA) in the Statistica 12.0 program. The significance of differences was determined with Tukey's test at $p<0.05$.

\section{Weather conditions}

Weather conditions during 2011-2013 are presented in Table1. The growing season of 2011 was characterized by favorable conditions for plant growth and development, and average monthly temperatures approximated the long-term average.

Table 1. Mean air temperature and rainfalls in the years 2011-2013

\begin{tabular}{|c|c|c|c|c|c|c|c|}
\hline \multirow[t]{2}{*}{ Years } & \multicolumn{6}{|c|}{ The vegetation period } & \multirow[t]{2}{*}{ Mean } \\
\hline & IV & V & VI & VII & VIII & IX & \\
\hline \multicolumn{8}{|c|}{ Mean air temperature $\left({ }^{\circ} \mathrm{C}\right)$} \\
\hline 2011 & 9.1 & 13.1 & 17.1 & 17.9 & 17.6 & 14.1 & 14.8 \\
\hline 2012 & 7.8 & 13.4 & 15.0 & 19.0 & 17.7 & 13.5 & 14.4 \\
\hline 2013 & 5.9 & 14.8 & 17.5 & 18.0 & 17.4 & 11.3 & 14.2 \\
\hline Multi-year & 7.7 & 13.5 & 16.1 & 18.7 & 17.9 & 12.8 & 14.5 \\
\hline \multicolumn{8}{|c|}{ Rainfalls (mm) } \\
\hline 2011 & 22.5 & 51.1 & 81.7 & 202.8 & 82.1 & 67.5 & 84.6 \\
\hline 2012 & 73.1 & 51.1 & 103.2 & 121.0 & 45.1 & 45.7 & 73.3 \\
\hline 2013 & 28.5 & 54.5 & 61.2 & 121.9 & 37.6 & 101.1 & 67.5 \\
\hline Multi-year & 33.3 & 58.5 & 80.4 & 74.2 & 59.4 & 56.9 & 60.5 \\
\hline
\end{tabular}


With the exception of April and October, total precipitation in 2011 exceeded the long-term average, and rainfall levels in July were nearly four-times higher than the long-term average. The second year of full utilization was characterized by moderate average temperatures, high precipitation in April, June and July, and a minor water deficit in August and September. In 2013, weather conditions were less favorable for plant growth due to low temperatures in early spring and considerable rainfall deficiency in June and August.

\section{Results and discussion \\ Proportion of alfalfa in sward of mixtures}

The proportion of alfalfa plants in the analyzed sward of mixtures differed considerably from the proportion of sown seeds. In the first year of full utilization, alfalfa developed at a much slower rate than in successive years of the study. In the first spring cut, alfalfa accounted for $20 \%$ to $37 \%$ of the sward, and its proportion was lower relative to the percentage of alfalfa seeds sown in the tested mixtures (Fig. 1). The proportion of alfalfa continued to increase after every successive harvest and reached $54-57 \%$ in the third-cut herbage. The greatest increase was noted in the mixture sown with $30 \% \mathrm{Mm}$ seeds and $70 \% \mathrm{Fb}$ seeds. Alfalfa plants develop a deep and extensive root system in initial stages of growth, which slows down the development of aerial biomass and increases the competitive advantage of grasses. The production of aerial biomass is intensified after successive harvests when alfalfa plants draw upon the nutrient reserves accumulated in the root collar (Jelinowska and Staniak 2007, Vasileva and Naydenova 2017). Alfalfa developed rapidly in 2012 and 2013, and it was the predominant component of the analyzed mixtures in the second- and third-cut herbage when its proportions considerably exceeded the percentage of sown seeds. Sosnowski and Jankowski $(2010)$ and Gaweł $(2007,2008)$ also reported on the high competitive advantage of alfalfa over Festulolium in successive years of utilization. In the present study, hybrid alfalfa cv. Radius was highly competitive over Festulolium cv. Sulino, in particular during dry spells in April, June and August 2013. Due to its shallow root system, Festulolium is less drought tolerant than alfalfa, and its development was strongly inhibited in the above months.

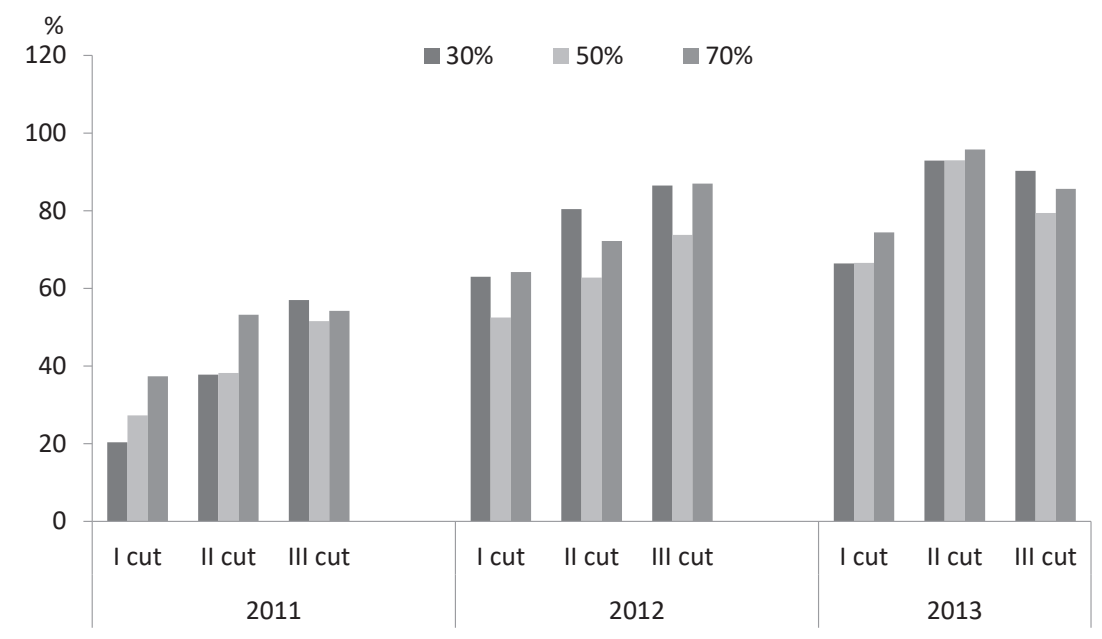

Fig. 1. The share of alfalfa in the yields of mixtures with various proportions of alfalfa $(30 \%, 50 \%, 70 \%)$

\section{Dry matter yield}

In the first year of full utilization, mixtures produced significantly higher yields than pure-sown alfalfa and puresown Festulolium (Table 2). The highest yield was noted in the mixture composed of $30 \%$ alfalfa and $70 \%$ Festulolium. The total dry matter yield of the above mixture was $13.5 \%$ higher in comparison with pure-sown alfalfa and $8.2 \%$ higher in comparison with pure-sown Festulolium. The mixtures containing $50 \%$ and $70 \%$ alfalfa produced somewhat lower yields, but not significantly different. At the first harvest, the highest yield was noted in puresown Festulolium, and the lowest yield was observed in pure-sown alfalfa. Reverse relationships were noted in the second- and third-cut herbage. In the first- and second-cut herbage, the differences in the yields of mixtures with various proportions of alfalfa were not significant, whereas at the third harvest, the mixture composed of $30 \% \mathrm{Mm}$ and $70 \% \mathrm{Fb}$ was characterized by a significantly higher yield, than the mixture of $70 \% \mathrm{Mm}$ and $30 \% \mathrm{Fb}$. 
In the second year of full utilization, mixture yields were determined in the range of $10.78-11.58 \mathrm{Mg} \mathrm{ha}^{-1}$ and were approximately $47 \%$ higher relative to the yield of pure-sown Festulolium (Table 2). The highest yield was noted in the $70 \% \mathrm{Mm}+30 \% \mathrm{Fb}$ mixture, and it was comparable to that of pure-sown alfalfa. Regardless of the botanical composition of the sward, the first-cut herbage had the highest share, and the third-cut herbage had the lowest share of total yield.

\begin{tabular}{|c|c|c|c|c|}
\hline Treatment & I cut & II cut & III cut & Sum \\
\hline & \multicolumn{4}{|c|}{2011} \\
\hline Mm 100\% & $2.96 \mathrm{a}$ & $3.48 b$ & $3.80 \mathrm{bc}$ & $10.24 \mathrm{a}$ \\
\hline $\mathrm{Fb} 100 \%$ & $5.00 \mathrm{c}$ & $2.94 \mathrm{a}$ & $2.81 \mathrm{a}$ & $10.74 \mathrm{~b}$ \\
\hline Mm70\%+ Fb30\% & $4.30 \mathrm{~b}$ & $3.01 \mathrm{ab}$ & $3.60 \mathrm{~b}$ & $10.91 \mathrm{bc}$ \\
\hline Mm50\%+ Fb50\% & $3.96 \mathrm{~b}$ & $3.23 \mathrm{ab}$ & $3.97 \mathrm{~cd}$ & $11.15 b c$ \\
\hline \multirow[t]{2}{*}{$\mathrm{Mm} 30 \%+\mathrm{Fb} 70 \%$} & $4.39 \mathrm{~b}$ & $3.01 \mathrm{ab}$ & $4.22 \mathrm{~d}$ & $11.62 \mathrm{c}$ \\
\hline & \multicolumn{4}{|c|}{2012} \\
\hline Mm 100\% & $5.75 \mathrm{c}$ & $3.73 c$ & $2.45 c$ & $11.93 \mathrm{c}$ \\
\hline Fb $100 \%$ & $3.70 \mathrm{a}$ & $2.58 \mathrm{a}$ & $1.08 \mathrm{a}$ & $7.35 \mathrm{a}$ \\
\hline Mm70\%+ Fb30\% & $5.55 \mathrm{c}$ & $3.72 \mathrm{c}$ & $2.30 \mathrm{bc}$ & $11.58 \mathrm{c}$ \\
\hline Mm50\%+ Fb50\% & $5.38 \mathrm{c}$ & $3.25 \mathrm{~b}$ & $2.15 \mathrm{~b}$ & $10.78 \mathrm{~b}$ \\
\hline \multirow[t]{2}{*}{ Mm30\%+Fb70\% } & $4.98 \mathrm{~b}$ & $3.65 c$ & $2.18 \mathrm{bc}$ & $10.80 \mathrm{~b}$ \\
\hline & \multicolumn{4}{|c|}{2013} \\
\hline Mm 100\% & $4.83 \mathrm{~b}$ & $3.60 \mathrm{~b}$ & $2.88 \mathrm{~d}$ & $11.30 \mathrm{c}$ \\
\hline $\mathrm{Fb} 100 \%$ & $2.63 \mathrm{a}$ & $1.13 \mathrm{a}$ & $0.68 \mathrm{a}$ & $4.43 \mathrm{a}$ \\
\hline Mm70\%+ Fb30\% & $4.53 \mathrm{~b}$ & $3.43 \mathrm{~b}$ & $2.35 c$ & $10.30 \mathrm{bc}$ \\
\hline Mm50\%+ Fb50\% & $4.45 b$ & $3.18 \mathrm{~b}$ & $1.88 \mathrm{~b}$ & $9.50 \mathrm{~b}$ \\
\hline \multirow[t]{2}{*}{ Mm30\%+ Fb70\% } & $4.53 \mathrm{~b}$ & $3.28 \mathrm{~b}$ & $2.50 \mathrm{~cd}$ & $10.30 \mathrm{bc}$ \\
\hline & \multicolumn{4}{|c|}{ 2011-2013 } \\
\hline Mm 100\% & $4.51 \mathrm{~b}$ & $3.60 \mathrm{c}$ & $3.04 \mathrm{~d}$ & $11.15 \mathrm{c}$ \\
\hline $\mathrm{Fb} 100 \%$ & $3.77 \mathrm{a}$ & $2.21 \mathrm{a}$ & $1.52 \mathrm{a}$ & $7.51 \mathrm{a}$ \\
\hline Mm70\%+ Fb30\% & $4.79 \mathrm{~b}$ & $3.39 \mathrm{bc}$ & $2.75 \mathrm{bc}$ & $10.93 c$ \\
\hline Mm50\%+ Fb50\% & $4.59 \mathrm{~b}$ & $3.22 \mathrm{~b}$ & $2.66 \mathrm{~b}$ & $10.47 \mathrm{~b}$ \\
\hline $\mathrm{Mm} 30 \%+\mathrm{Fb} 70 \%$ & $4.63 \mathrm{~b}$ & $3.31 \mathrm{~b}$ & $2.97 \mathrm{~cd}$ & $10.91 \mathrm{c}$ \\
\hline
\end{tabular}

$\mathrm{Mm}=$ Medicago media; $\mathrm{Fb}=$ Festulolium braunii
Values within a column marked with different letter are significantly different at $p<0.05$

In the last year of the study, the highest yield was noted in pure-sown alfalfa $\left(11.30 \mathrm{Mg} \mathrm{ha}{ }^{-1}\right)$, whereas somewhat lower yields were observed in mixtures, in particular in the mixture with equal proportions (50\%) of both components. In the $50 \% \mathrm{Mm}+50 \% \mathrm{Fb}$ mixture, yields were approximately $16 \%$ lower than in pure-sown alfalfa and more than twice higher than in pure-sown Festulolium. Similarly to the previous years of the study, the first-cut herbage had the highest share of total yield. In successive years, the greatest decrease in yield was observed in pure-sown Festulolium. The dry matter yield of Festulolium decreased by $32 \%$ in the second year and by $59 \%$ in the third year of the experiment, which suggests that alfalfa grown in mixtures stabilized yields in growing seasons with variable weather conditions. The yields of the analyzed mixtures were higher and more stable in comparison with the yields of pure-sown species due to better utilization of space, different growth and development rates of mixture components, and more complementary utilization of environmental resources (Vasileva and Vasilev 2012, Luscher et al. 2014, Vasileva and Ilieva 2016, Staniak and Harasim 2018).

An analysis of average annual dry matter yields over three years revealed that the yields of the mixtures containing $30 \%$ and $70 \%$ alfalfa were similar to the yields of pure-sown alfalfa and around $6 \%$ higher than the yield of the mixture containing $50 \%$ alfalfa. Pure-sown Festulolium was characterized by the lowest average annual dry matter yield. 


\section{Content and yield of crude protein}

Protein is the most expensive component of ruminant feeds, and protein yields significantly affect production profitability. The average total protein yield during the 3-year studies was lowest in pure-sown Festulolium $(0.81 \mathrm{Mg}$ $\left.\mathrm{ha}^{-1}\right)$ and highest in pure-sown alfalfa $\left(1.90 \mathrm{Mg} \mathrm{ha}^{-1}\right)$. The mixtures containing alfalfa were characterized by significantly higher protein yield per unit area than pure sown Fb (Table 3). Subject to the proportion of alfalfa seeds in the seed mixture, the protein yield of mixtures was approximately 73-96\% higher than in pure-sown Festulolium and approximately $16-26 \%$ lower than in pure-sown alfalfa. In the group of the analyzed mixtures, protein yield was lowest in the mixture containing $50 \%$ alfalfa $\left(1.40 \mathrm{Mg} \mathrm{ha}^{-1}\right)$. Protein yields were higher and similar in the mixtures containing $30 \%$ and $70 \%$ alfalfa. Minor differences in the protein yield of pure-sown alfalfa and mixtures and a clear decrease in the protein yield of pure-sown Festulolium were observed across the experimental years. An analysis of the average values for the 3-year experiment revealed that protein yields were highest in the first-cut herbage and continued to decrease after successive harvests (Table 3 ).

\begin{tabular}{|c|c|c|c|c|}
\hline Treatment & I cut & II cut & III cut & Sum \\
\hline & \multicolumn{4}{|c|}{2011} \\
\hline Mm 100\% & $0.53 a b$ & $0.62 c$ & $0.65 c$ & $1.80 \mathrm{~d}$ \\
\hline Fb $100 \%$ & $0.49 a$ & $0.26 \mathrm{a}$ & $0.28 \mathrm{a}$ & $1.03 \mathrm{a}$ \\
\hline Mm70\%+ Fb30\% & $0.58 b$ & $0.39 \mathrm{~b}$ & $0.43 \mathrm{~b}$ & $1.39 \mathrm{~b}$ \\
\hline Mm50\%+ Fb50\% & $0.51 \mathrm{ab}$ & $0.40 \mathrm{~b}$ & $0.45 b$ & $1.36 \mathrm{~b}$ \\
\hline \multirow[t]{2}{*}{$\mathrm{Mm} 30 \%+\mathrm{Fb} 70 \%$} & $0.54 \mathrm{ab}$ & $0.40 \mathrm{~b}$ & $0.59 \mathrm{c}$ & $1.52 \mathrm{c}$ \\
\hline & \multicolumn{4}{|c|}{2012} \\
\hline Mm 100\% & $0.88 d$ & $0.63 d$ & $0.42 c$ & $1.93 \mathrm{e}$ \\
\hline $\mathrm{Fb} 100 \%$ & $0.37 \mathrm{a}$ & $0.30 \mathrm{a}$ & $0.15 \mathrm{a}$ & $0.82 \mathrm{a}$ \\
\hline $\mathrm{Mm70 \% +Fb30 \%}$ & $0.75 c$ & $0.54 \mathrm{c}$ & $0.41 b c$ & $1.71 \mathrm{~d}$ \\
\hline $\mathrm{Mm50 \% +Fb50 \%}$ & $0.56 \mathrm{~b}$ & $0.39 \mathrm{~b}$ & $0.37 \mathrm{~b}$ & $1.31 \mathrm{~b}$ \\
\hline \multirow[t]{2}{*}{$\mathrm{Mm30 \% +Fb70 \%}$} & $0.54 \mathrm{~b}$ & $0.57 c$ & $0.40 \mathrm{bc}$ & $1.51 \mathrm{c}$ \\
\hline & \multicolumn{4}{|c|}{2013} \\
\hline Mm 100\% & $0.93 \mathrm{c}$ & $0.59 \mathrm{~b}$ & $0.46 \mathrm{~d}$ & $1.97 \mathrm{c}$ \\
\hline Fb $100 \%$ & $0.31 \mathrm{a}$ & $0.16 a$ & $0.11 \mathrm{a}$ & $0.58 \mathrm{a}$ \\
\hline $\mathrm{Mm70 \% +Fb30 \%}$ & $0.71 \mathrm{~b}$ & $0.58 \mathrm{~b}$ & $0.38 c$ & $1.67 \mathrm{~b}$ \\
\hline Mm50\%+ Fb50\% & $0.72 b$ & $0.52 \mathrm{~b}$ & $0.29 \mathrm{~b}$ & $1.53 \mathrm{~b}$ \\
\hline \multirow[t]{2}{*}{$\mathrm{Mm30 \% +Fb70 \%}$} & $0.75 b$ & $0.54 \mathrm{~b}$ & $0.39 c$ & $1.68 \mathrm{~b}$ \\
\hline & \multicolumn{4}{|c|}{ 2011-2013 } \\
\hline $\mathrm{Mm} 100 \%$ & $0.78 d$ & $0.61 \mathrm{~d}$ & $0.51 \mathrm{e}$ & $1.90 \mathrm{~d}$ \\
\hline Fb 100\% & $0.39 a$ & $0.24 a$ & $0.18 \mathrm{a}$ & $0.81 \mathrm{a}$ \\
\hline Mm70\%+ Fb30\% & $0.38 c$ & $0.50 \mathrm{c}$ & $0.41 \mathrm{c}$ & $1.59 \mathrm{c}$ \\
\hline $\mathrm{Mm} 50 \%+\mathrm{Fb} 50 \%$ & $0.60 \mathrm{~b}$ & $0.44 \mathrm{~b}$ & $0.37 \mathrm{~b}$ & $1.40 \mathrm{~b}$ \\
\hline Mm30\%+Fb70\% & $0.61 \mathrm{~b}$ & $0.50 \mathrm{c}$ & $0.46 \mathrm{~d}$ & $1.57 \mathrm{c}$ \\
\hline
\end{tabular}

$\mathrm{Mm}=$ Medicago media, $\mathrm{Fb}=$ Festulolium braunii

Values within a column marked with different letter are significantly different at $p<0.05$.

Protein yield was calculated based on the dry matter yield and the CP content of plants. Pure-sown alfalfa was characterized by the highest average protein content which was determined at $168.0 \mathrm{~g} \mathrm{~kg}^{-1}$ on a dry matter basis and was $70 \%$ higher than in pure-sown Festulolium (Fig. 2). The protein content of the evaluated mixtures ranged from 138.3 to $148.0 \mathrm{~g} \mathrm{~kg}^{-1}$ and was $17.5-25.7 \%$ higher than in pure-sown Festulolium and $11.9-17.7 \%$ lower than in pure-sown alfalfa, subject to the proportion of alfalfa seeds in the analyzed mixture. The mixture with equal proportions (50\%) of both components was characterized by the lowest protein content. The remaining mixtures did not differ with regard to the above parameter. Only minor differences were found in the protein content of successive cuts. The protein content of pure-grown Festulolium increased at successive harvests, whereas the reverse was observed in pure-grown alfalfa. 


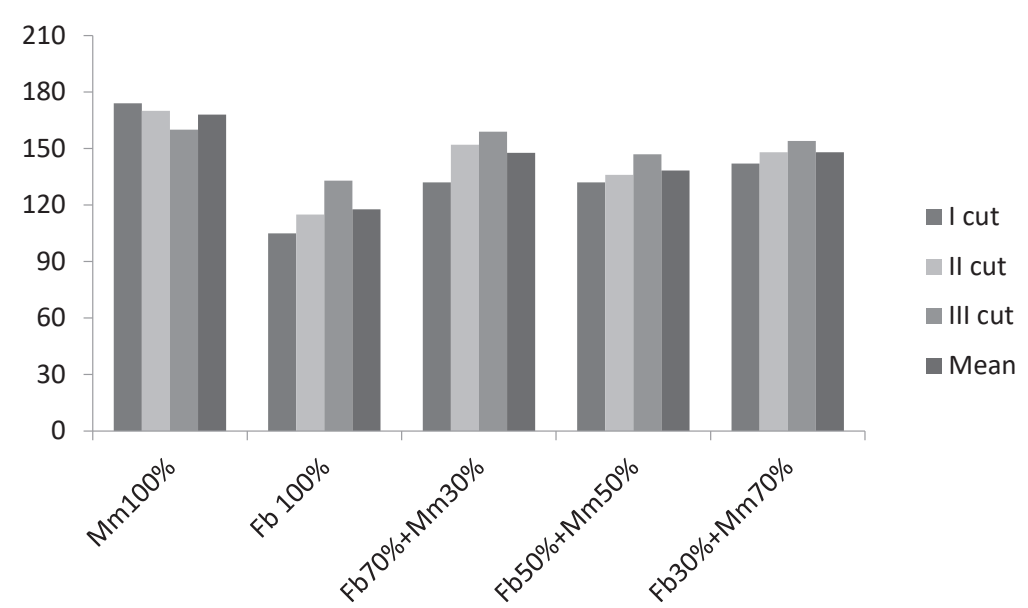

Fig. 2. Content of crude protein (average for years)

\section{Content and yield of water-soluble carbohydrates}

The energy content of feeds determines the utilization of feed proteins. Water-soluble carbohydrates play an important role in cattle nutrition as the main source of highly available energy for microbiological processes in the rumen (Evans et al. 2011, Jafari 2012). In our study, pure-sown Festulolium was characterized by the highest average total WSC yield (1.10 Mg ha-1) which was approximately $156 \%$ higher relative to pure-sown alfalfa $(0.44 \mathrm{Mg}$ $\left.\mathrm{ha}^{-1}\right)$. As a result, the WSC yield of the mixtures containing Festulolium was higher. Depending on the composition of the analyzed mixtures, their WSC yields were around $72-100 \%$ higher relative to pure-sown alfalfa. The mixtures containing $30 \%$ and $50 \%$ alfalfa produced significantly higher WSC yields than the mixture containing $70 \%$ alfalfa (Table 4). The above trend was observed in the first and second year of full utilization. In pure-sown FestuIolium and in the mixtures, the average WSC yields were highest in the first-cut herbage, whereas the WSC yields of pure-sown alfalfa did not differ significantly between harvests.

\begin{tabular}{|c|c|c|c|c|}
\hline Treatment & I cut & II cut & III cut & Sum \\
\hline & \multicolumn{4}{|c|}{2011} \\
\hline Mm 100\% & $0.16 \mathrm{a}$ & $0.09 a$ & $0.18 \mathrm{a}$ & $0.43 a$ \\
\hline Fb 100\% & $0.84 \mathrm{~d}$ & $0.28 \mathrm{~d}$ & $0.37 d$ & $1.49 \mathrm{e}$ \\
\hline $\mathrm{Mm} 70 \%+\mathrm{Fb} 30 \%$ & $0.44 \mathrm{~b}$ & $0.12 b$ & $0.29 c$ & $0.85 b$ \\
\hline $\mathrm{Mm} 50 \%+\mathrm{Fb} 50 \%$ & $0.54 \mathrm{c}$ & $0.13 b$ & $0.40 \mathrm{e}$ & $1.07 \mathrm{~d}$ \\
\hline \multirow[t]{2}{*}{$\mathrm{Mm} 30 \%+\mathrm{Fb} 70 \%$} & $0.51 \mathrm{c}$ & $0.16 \mathrm{c}$ & $0.26 b$ & $0.93 c$ \\
\hline & \multicolumn{4}{|c|}{2012} \\
\hline Mm 100\% & $0.13 a$ & $0.19 a$ & $0.12 \mathrm{a}$ & $0.44 a$ \\
\hline $\mathrm{Fb} 100 \%$ & $0.31 \mathrm{e}$ & $0.29 c$ & $0.11 \mathrm{a}$ & $0.71 \mathrm{~d}$ \\
\hline $\mathrm{Mm} 70 \%+\mathrm{Fb} 30 \%$ & $0.25 d$ & $0.22 b$ & $0.17 b$ & $0.64 \mathrm{c}$ \\
\hline Mm50\%+ Fb50\% & $0.17 \mathrm{~b}$ & $0.20 \mathrm{~b}$ & $0.20 \mathrm{c}$ & $0.57 \mathrm{~b}$ \\
\hline \multirow[t]{2}{*}{$\mathrm{Mm} 30 \%+\mathrm{Fb} 70 \%$} & $0.21 \mathrm{c}$ & $0.35 \mathrm{~d}$ & $0.23 \mathrm{~d}$ & $0.80 \mathrm{e}$ \\
\hline & \multicolumn{4}{|c|}{ 2011-2012 } \\
\hline Mm 100\% & $0.15 \mathrm{a}$ & $0.14 \mathrm{a}$ & $0.15 \mathrm{a}$ & $0.44 \mathrm{a}$ \\
\hline Fb 100\% & $0.57 c$ & $0.29 \mathrm{~d}$ & $0.24 b$ & $1.10 \mathrm{~d}$ \\
\hline Mm70\%+Fb30\% & $0.34 \mathrm{~b}$ & $0.17 b$ & $0.23 \mathrm{~b}$ & $0.74 \mathrm{~b}$ \\
\hline $\mathrm{Mm50 \% +Fb50 \%}$ & $0.35 \mathrm{~b}$ & $0.17 \mathrm{~b}$ & $0.30 \mathrm{c}$ & $0.82 \mathrm{c}$ \\
\hline $\mathrm{Mm} 30 \%+\mathrm{Fb} 70 \%$ & $0.36 \mathrm{~b}$ & $0.26 \mathrm{c}$ & $0.25 b$ & $0.86 \mathrm{c}$ \\
\hline
\end{tabular}

$\mathrm{Mm}=$ Medicago media, $\mathrm{Fb}=$ Festulolium braunii

Values within a column marked with different letter are significantly different at $p<0.05$. 
The WSC yield was determined by the WSC content of dry matter. The biomass of pure-sown alfalfa was characterized by very low WSC content (Fig. 3). This was estimated at $40 \mathrm{~g} \mathrm{~kg}^{-1}$ and was more than 2.5 -fold lower than in pure-sown Festulolium. The combination of alfalfa and Festulolium in the mixtures increased WSC concentrations and improved the feed value of green fodder. The average WSC content in the mixtures composed of $30 \%$ and $50 \%$ alfalfa reached 79.4 and $77.5 \mathrm{~g} \mathrm{~kg}^{-1}$, respectively, and it was much lower in the mixture containing $70 \%$ alfalfa $\left(66.6 \mathrm{~g} \mathrm{~kg}^{-1}\right)$. Differences in WSC content were also noted during the growing season. Carbohydrate concentrations were highest in the first-cut herbage of pure-sown Festulolium. In all treatments, the WSC content of dry matter was lowest in the second-cut herbage, in particular in the mixtures containing $50 \%$ and $70 \%$ alfalfa. Carbohydrate concentrations increased in the third-cut herbage. Similar results were reported by other authors who noted considerable variations in the WSC content during the growing season (Ciepiela 2014, Purwin et al. 2016). According to Griggs et al. (2005), the WSC content of grasses is highest in spring, lower in summer, and it increases again in autumn. The decrease in the WSC content of plants in summer can be attributed to high temperatures and high humidity. High air temperatures increase respiration and speed up sugar depletion in plants. Light exposure also plays a role in sugar accumulation in plant tissues. Sunlight increases the rate of photosynthesis, which directly influences sugar production and leads to variations in carbohydrate content during the growing season (Jafari 2012).

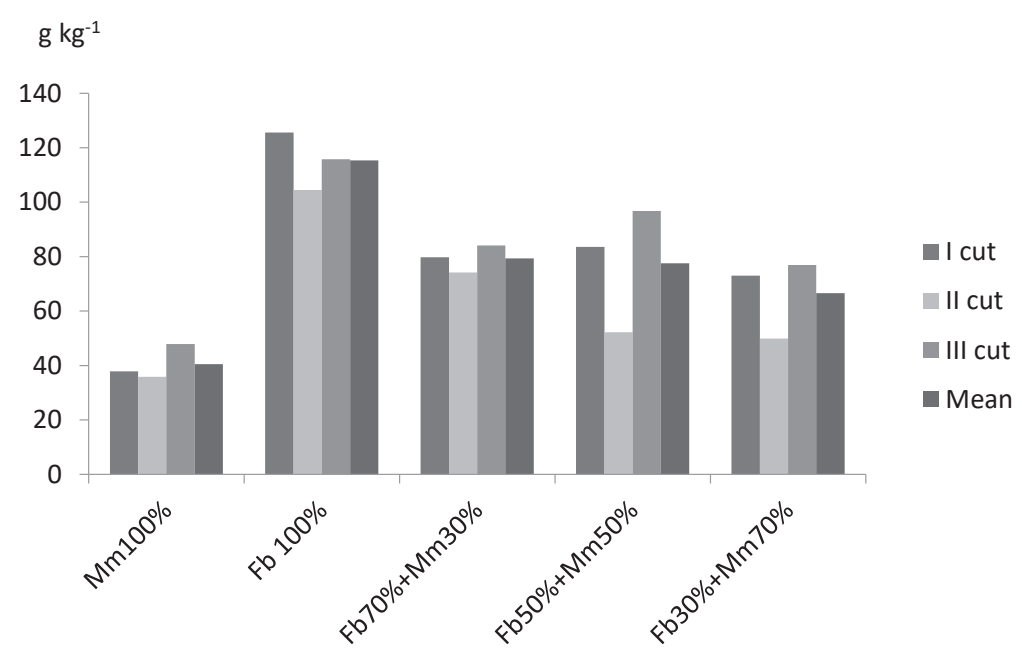

Fig. 3. Content of water-soluble carbohydrates (average for years)

\section{Carbohydrate-to-protein ratio}

The WSC:CP ratio is an indicator of protein availability for animals (Jafari 2012, Simili da Silva et al. 2013, Huhtanen and Broderick 2016). For ruminants, the optimal value of the WSC:CP ratio is $0.8-1.5$, and it should not be lower than 0.4. In our study, a desirable WSC:CP ratio was noted only in the biomass of pure-sown Festulolium (Fig. 4). In the biomass of pure-sown alfalfa, the analyzed parameter was determined at 0.25 on average, and it was below the minimum value. The evaluated mixtures were characterized by more favorable WSC:CP ratios $(0.49-0.61)$, but the noted values did not meet the nutrient requirements of ruminants. The above can be attributed to the high proportions of alfalfa in the tested mixtures. Similar values of the WSC:CP ratio were reported by Simili da Silva et al. (2013) in legume and grass mixtures. In our study, the WSC:CP ratio was least favorable in the second-cut herbage, which can be attributed to its low carbohydrate content.

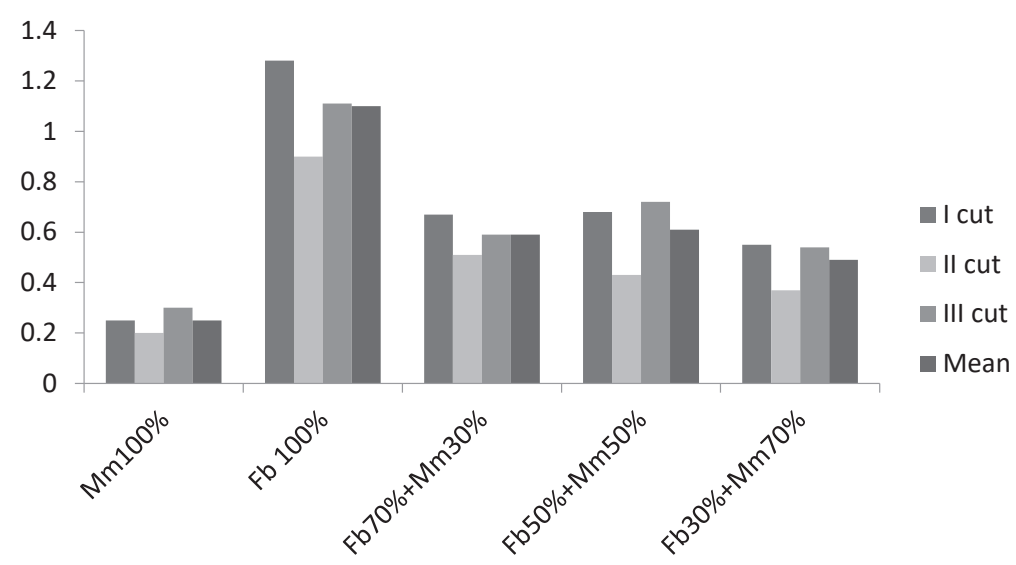

Fig. 4. Carbohydrate-to-protein ratio (average for years) 


\section{Conclusions}

The results of the study indicate that Medicago media has a high competitive advantage over Festulolium braunii. The proportion of alfalfa in the biomass of the tested mixtures increased in successive years of the experiment. In the second and third year of full utilization, alfalfa was the predominant sward species regardless of the proportion of alfalfa seeds in the mixture. During the growing season, the proportion of alfalfa was lowest in the first-cut herbage, and the species developed rapidly in the second and third harvest cycle. The analyzed mixtures were characterized by a higher feed value than pure-sown alfalfa and pure-sown Festulolium. The presence of alfalfa in the evaluated mixtures increased and stabilized dry matter and CP yields, whereas the presence of Festulolium braunii significantly increased the content of WSC and improved the WSC:CP ratio. Sward mixtures with equal proportions (50\%) of both components were characterized by the lowest dry matter and CP yields. The above parameters were higher and similar in the mixtures containing $30 \%$ and $70 \%$ alfalfa. Carbohydrate yields and the WSC:CP ratio were higher in the mixtures with $30 \%$ and $50 \%$ alfalfa than in the mixture with $70 \%$ alfalfa. The results of this study indicate that Festulolium and alfalfa mixtures with a lower proportion of alfalfa (30\% and $50 \%)$ have a higher feed value.

\section{References}

Andrzejewska, J., Albrecht, K.A. \& Jędrzejczak, E. 2013. Wysokość roślin a wartość paszowa lucerny w różnych fazach rozwojowych i w pokosach. Fragmenta Agronomica 30: 14-22. (in Polish).

Broderick, G.A. 1995. Desirable characteristics of forage legumes for improving protein utilization in ruminants. Journal of Animal Science 73: 2760-2773. https://doi.org/10.2527/1995.7392760x

Ciepiela, G.A. 2014. Zawartość węglowodanów strukturalnych i niestrukturalnych oraz ligniny w Dactylis glomerata L. i Festulolium braunii (K. Richt.) A. Camus zasilanych biostymulatorem Kelpak SL i azotem. Nauka Przyroda Technologie 8: 1-12. (in Polish).

Evans, J.G., Fraser, M.D., Owen, I., \& Davies, D.A. 2011. An evaluation of two perennial ryegrass cultivars (AberDart and Fennema) for sheep production in the uplands. Journal of Agricultural Science 149: 235-248. https://doi.org/10.1017/S0021859610001048

Gaweł, E. 2007. Wpływ sposobu i częstotliwości użytkowania na plon i trwałość lucerny mieszańcowej w mieszankach wielogatunkowych. Fragmenta Agronomica 24: 110-120. (in Polish).

Gaweł, E. 2008. Wpływ sposobów i różnej częstotliwości użytkowania mieszanek lucerny mieszańcowej (Medicago sativa L. x varia T. Martyn) z trawami na plon, jego skład botaniczny i jakość. Woda Środowisko Obszary Wiejskie 24: 5-18. (in Polish).

Griggs, T.C., MacAdam, J.W., Mayland, H.F. \& Burns, J.C. 2005. Nonstructural carbohydrate and digestibility patterns in orchardgrass swards during daily defoliation sequences initiated in evening and morning. Crop Science 45: 1295-1304. https://doi. org/10.2135/cropsci2003.0613

Huhtanen, P. \& Broderick, G. 2016. Improving utilisation of forage protein in ruminant production by crop and feed management. Grass Forage Science 61: 340-349.

Jafari, A.A. 2012. Environmental and genetic variation for water soluble carbohydrate content in cool season forage grasses. In: Chang, C.F. (ed.). Carbohydrates-Comprehensive Studies on Glycobiology and Glycotechnology. IntechOpen. p. 373-388. https:// doi.org/10.5772/51575

Jankowski, K., Truba, M., Wiśniewska-Kadżajan, B., Sosnowski, J. \& Malinowska, E. 2018. The effect of soil conditioners on yield of dry matter, protein and sugar in grass. Acta Agrophysica 25: 45-58. https://doi.org/10.31545/aagr0004

Jelinowska, A., \& Staniak, M. 2007. Wzajemne oddziaływanie roślin w siewach jednogatunkowych i mieszanych na przykładzie lucerny z trawami. Postępy Nauk Rolniczych 5: 37-49. (in Polish).

Johansen, M., Søegaard, K. \& Weisbjerg, M.R. 2016. Leaf:stem ratio as a tool to estimate field losses. Evaluation in dairy cows in early lactation. Grass and Forage Science 61: 232-234.

Lüscher, A., Mueller-Harve, I. Soussana, I.F., Rees, R.M. \& Peyraud, J.L. 2014. Potential of legume-based grassland-livestock systems in Europe: a review. Grass and Forage Science 69: 206-228. https://doi.org/10.1111/gfs.12124

Mäkiniemi, K., Niskanen, M. \& Seppänen, M. 2016. Optimization of the harvesting time of pure lucerne (Medicago sativa L.) swards in Finland. Grassland Science in Europe 21: 290-292.

Miller, L.A., Moorby, J.M., Davies, D.R., Humphreys, M.O., Scollan, N.D., MacRae, J.C. \& Theodorou, M.K. 2001. Increased concentration of water-soluble carbohydrate in perennial ryegrass (Lolium perenne L.). Milk production from late-lactation dairy cows. Grass and Forage Science 56: 383-394. https://doi.org/10.1046/j.1365-2494.2001.00288.x

Olszewska, M. \& Kobyliński, A. 2016. Leaf greenness and yield of grass mixtures containing Medicago media Pers. with varied proportions of mixture components. Romanian Agricultural Research 33: 145-152. http://www.incda-fundulea.ro/rar/nr33/rar33.16.pdf

Peyraud, J.L. \& Peeters, A. 2016. The role of grassland based production system in the protein security. The multiple roles of grassland in the European bioeconomy. Grassland Science in Europe 21: 29-43.

Peyraud, J.L., van den Pol-Van Dasselaar, A., Collins, R., Huguenin-Elie, O., Dillon, P. \& Peeters, A. 2014. Multispecies swards and multi scale strategies for multifunctional grassland-base ruminant production system: an overview of the FP7-MultiSward Project. The Future of European Grasslands. Grassland Science in Europe 19: 695-715. 
Purwin, C., Stanek, M., Lipiński, K., Wierzbowska, J., Nogalska, A. \& Fijałkowska, M. 2016. Effect of a harvest time and cultivar on the chemical composition and in vitro ruminal dry matter degradability of perennial ryegrass (Lolium perenne L.). Journal of Elementology 21: 811-822. https://doi.org/10.5601/jelem.2015.20.4.1039

Seppänen, M.M., Alitalo, V., Bäckström, H.K, Mäkiniemi, K., Jokela, V., Falghera-Winseman, L. \& Khazaei, H. 2018. Growth, freezing tolerance, and yield performance of alfalfa (Medicago sativa L.) cultivars grown under controlled and field conditions in northern latitudes. Canadian Journal of Plant Science 98: 1109-1118. https://doi.org/10.1139/cjps-2017-0305

Simili da Silva, M., Tremblay, G.F., Bélanger, G., Lajeunesse, J., Papadopoulos, Y.A., Fillmore, S.A.E. \& Jobim, C.C. 2013. Energy to protein ratio of grass-legume binary mixtures under frequent clipping. Agronomy Journal 105: 482-492. https://doi.org/10.2134/ agronj2012.0281

Sosnowski, J. \& Jankowski, K. 2010. Wpływ użyźniacza glebowego na skład florystyczny i plonowanie mieszanek kostrzycy Brauna z koniczyną łąkowa i lucerną mieszańcową. Łąkarstwo w Polsce 13: 157-166. (in Polish).

Sosnowski, J. 2011. Wartość paszowa mieszanek Festulolium braunii z koniczyną łąkową i lucerną mieszańcową zasilanych użyźniaczem glebowym. Łąkarstwo w Polsce 14: 127-135. (in Polish).

Staniak, M. 2016. The impact of drought stress on the yields and food value of selected forage grasses. Acta Agrobotanica 69: 1663-1675. https://doi.org/10.5586/aa.1663

Staniak, M. \& Harasim, E. 2018. Changes in nutritive value of alfalfa (Medicago * varia T. Martyn) and Festulolium (Festulolium braunii (K. Richt.) A. Camus) under drought stress. Journal of Agronomy and Crop Science 204: 456-466. https://doi.org/10.1111/jac.12271 Systematyka gleb Polski 1989. Roczniki Gleboznawcze. Państwowe Wydawnictwo Naukowe. 62 p. (in Polish).

Vasileva, V. \& Ilieva, A. 2016. Sustainable yield index in some mixtures. Journal of Global Innovations in Agricultural and Social Sciences 4: 55-61. https://doi.org/10.22194/JGIASS/4.2.741

Vasileva, V. \& Naydenova, Y. 2017. Nutritive value of forage biomass from mixtures of alfalfa with cocksfoot and tall fescue. Journal of Global Innovations in Agricultural and Social Sciences 5: 121-129.

Vasileva, V. \& Vasilev, E. 2012. Study on Productivity of some Legume Crops in Pure Cultivation and Mixtures. Agriculturae Conspectus Scientificus 77: 91-94. 